\title{
IMPLEMENTACJA ZARZADZANIA PROCESOWEGO - STUDIUM PRZYPADKU PRZEDSIĘBIORSTWA PRODUKCYJNEGO
}

DOI: 10.33141/po.2020.02.02

\author{
Piotr Bartkowiak, Izabela Grabowska
}

Przegląd Organizacji, Nr 2(961), 2020, s. 10-19 www.przegladorganizacji.pl ๑ Towarzystwo Naukowe Organizacji i Kierownictwa (TNOiK)

\section{Wprowadzenie}

$\mathbf{Z}$ arządzanie procesowe jest jedną $\mathrm{z}$ najpopularniejszych koncepcji zarządzania we współczesnych organizacjach ze względu na wymagania stawiane przez gospodarkę opartą na wiedzy oraz szanse, jakie stwarzają nowe technologie ICT (Szelągowski, 2015, s. 29). Implementacja zarządzania procesowego $\mathrm{w}$ gospodarce wiedzy jest zupełnie odmienna niż implementacja tego zarządzania w gospodarce przemysłowej (Jashapara, 2011).

W wyniku zachodzących w otoczeniu dynamicznych zmian, obejmujących wiele obszarów funkcjonowania współczesnych przedsiębiorstw, w literaturze przedmiotu wskazuje się na konieczność implementacji modelu architektury procesów zarówno w zakresie strategii, jak i działań operacyjnych (Bitkowska, 2019, s. 14).

Jak wskazuje A. Bitkowska (2016, s. 4), wdrożenie koncepcji zarządzania procesowego stwarza możliwości doskonalenia organizacji na wielu płaszczyznach, $\mathrm{w}$ tym tak istotnych, jak wzrost dochodów i udziału w rynku, wzrost skuteczności wykorzystania zasobów w celu podniesienia satysfakcji klientów, poprawa relacji z klientami, lepsza współpraca pomiędzy poszczególnymi działami, a także realizacja celów strategicznych przedsiębiorstwa.

Dla przedsiębiorstw wdrożenie koncepcji zarządzania procesowego jest zatem dużym wyzwaniem i szansą na osiągnięcie przewagi konkurencyjnej w zmiennym i globalizującym się otoczeniu rynkowym. Prawidłowa identyfikacja procesów, ich modelowanie oraz sprawne zarządzanie kluczowymi procesami stanowią często główny czynnik warunkujący elastyczność działania, rentowność, jak również satysfakcję klientów. Celem artykułu jest identyfikacja implementacji zarządzania procesowego, poprzedzona diagnozą faz wzrostu badanej organizacji oraz oceną powdrożeniową dojrzałości procesowej z wykorzystaniem Modelu Dojrzałości Procesów i Przedsiębiorstwa (ang. Process and Enterprise Maturity Medel, PEMM). Dla tak przyjętego celu w artykule wykorzystano analizę literatury przedmiotu, kwestionariusz ankiety oraz studium przypadku przedsiębiorstwa produkcyjnego prowadzącego działalność w Polsce.

\section{Znaczenie podejścia procesowego w przedsiębiorstwie}

D odejście procesowe to dynamiczne spojrzenie na organizację przez pryzmat realizowanych procesów. Integruje ono czas, terminowość realizacji działań, jakość oraz nastawienie na tworzenie wartości dla klienta, pozwalające na osiągnięcie efektu strategicznego w postaci elastyczności, będącej ważną przewagą konkurencyjną (Weiss, 2012, s. 264).

W praktyce zarządzania następuje odejście od organizacji klasycznej, która bazowała przede wszystkim na funkcjach i specjalnościach zawodowych, co pozwalało na kumulację wiedzy, doświadczenia i umiejętności. Nie koncentrowano się także na procesach, których głównym celem powinno być zaspokojenie potrzeb klientów (Brilman, 2002, s. 289). Zarządzanie procesowe promuje nakierowanie wszelkich działań organizacji na potrzeby klienta oraz przejrzystość zasad działania i odpowiedzialność wszystkich interesariuszy procesów (Bitkowska, 2013, s. 66; Cieśliński, 2011, s. 11). Najistotniejszy jest więc 
dynamizm procesów organizacyjnych, który jest wprost proporcjonalny do dynamizmu całej organizacji (Grajewski, 2012, s. 67). W praktyce gospodarczej, jak zauważa S. Nowosielski, najtrudniejsze wydaje się powiązanie celów strategicznych z celami procesów (Nowosielski, 2011 za: Bitkowska, 2016, s. 4). Badania empiryczne przeprowadzone w przedsiębiorstwach, które wdrożyły i stosują zarządzanie procesowe, wskazują, że najistotniejszymi czynnikami sprzyjającymi wdrażaniu tego zarządzania są: zorientowanie działań organizacji i jej pracowników na potrzeby klienta, zaangażowanie kadry kierowniczej na wprowadzanie rozwiązania oraz praca zespołowa (Bitkowska, 2016, s. 4-11).

Zdaniem P. Grajewskiego (2016), organizację procesową można zdefiniować jako system, który ukierunkowuje relacje między realizatorami jej celów, a działaniami zawartymi w zbiorach sekwencyjnych czynności, czyli procesów, które są ciągami działań transformującymi pomysł i wysiłek człowieka na efekt zdefiniowany przez oczekującego na niego klienta.

\section{Proces i metodyka zarządzania procesowego}

A utorzy M. Hammer i J. Champy (1996, s. 16) określają proces, jako czynność wymagającą na wejściu wkładu i dającą na wyjściu rezultat - pewną wartość dla klienta. Przebieg owych procesów, a także ich koszty i czas trwania mają decydujący wpływ na sprawność działania organizacji (Grajewski, 2016, s. 60). Zgodnie z interpretacją P. Grajewskiego, najczęściej w przedsiębiorstwach dokonuje się podziału procesów na: podstawowe, pomocnicze i zarządcze, których charakterystykę przedstawiono w tabeli 1.

Identyfikacja procesów $\mathrm{w}$ przedsiębiorstwie polega na wyszczególnieniu tych procesów, które w największym stopniu wpływają na sukces przedsiębiorstwa (Wójcik, 2011, s. 142). Podstawą identyfikacji procesów operacyjnych jest analiza i podział działalności przedsiębiorstwa $\mathrm{z}$ uwzględnieniem klientów, tworzenia wartości dodanej i innych uwarunkowań dotyczących jakości. Wyszczególnienie działalności powinno przebiegać w sposób umożliwiający wyodrębnienie niezależnych procesów, które powinny być skutecznie monitorowane i zarządzane pod kątem spełnienia wymagań wszystkich interesariuszy organizacji (Bitkowska i in., 2011, s. 10; Bartkowiak, Rutkowski, 2016, s. 35).

Literatura przedmiotu wyróżnia wiele metodyk realizacyjnych, według których odbywa się wdrożenie zarządzania procesowego. Wskazać można m.in. metodykę R. Talwara, która obejmuje cztery etapy wdrożenia (Winiowski, 2016, s. 21-22):

1. Zdefiniowanie strategii organizacji.

2. Budowa kompetencji niezbędnych do realizacji strategii.

3. Zaprojektowanie procesów podstawowych i systemu zarządzania nimi $\mathrm{z}$ uwzględnieniem posiadanych kompetencji.

4. Wdrożenie struktury procesowej w miejsce dotychczasowej, bazującej na podejściu funkcjonalnym.

Według J. Czekaja (2009, s. 49), wyróżnić można pięć etapów wdrożenia procesów w organizacji. Są to:

1. Identyfikacja potrzeb interesariuszy organizacji (zarówno wewnętrznych, jak i zewnętrznych, w tym $\mathrm{w}$ otoczeniu konkurencyjnym oraz szeroko rozumianym otoczeniu społecznym).

2. Zdefiniowanie i sklasyfikowanie procesów w organizacji.

3. Audyt efektywności i sprawności realizowanych procesów.

4. Zarządzanie procesami poprzez ich projektowanie, implementację i doskonalenie.

5. Audyt i kontrola skutków wdrożonych zmian.

Natomiast L. Winiowski (2016, s. 22) na podstawie obserwacji przedsiębiorstw przemysłowych zidentyfikował cztery fazy wdrożenia zarządzania procesowego:

1. Określenie celów nadrzędnych, dla których system zarządzania oparty na podejściu procesowym będzie stanowił układ wsparcia.

2. Zdefiniowanie i charakterystyka procesów.

3. Implementacja zaprojektowanych regulacji.

4. Pomiar efektywności i sprawności procesów.

Tabela 1. Klasyfikacja procesów w organizacji

\begin{tabular}{|c|c|}
\hline Proces & Charakterystyka \\
\hline Podstawowy & $\begin{array}{l}\text { - bezpośrednio generuje wartość dodaną; } \\
\text { - należą do niego działania marketingowe, sprzedażowe, projektowania nowych produktów oraz dystrybucja; } \\
\text { - klient najłatwiej je dostrzega i na ich podstawie ocenia jakość i sprawność działania całego przedsiębiorstwa. }\end{array}$ \\
\hline Pomocniczy & $\begin{array}{l}\text { - pośrednio generuje wartość dodaną; } \\
\text { - należą do niego działania magazynowania, kontroli jakości konserwacji i utrzymania ruchu, rekrutacji i oceny kadr oraz } \\
\text { obsługi finansowo-księgowej; } \\
\text { - klient słabo dostrzega ich jakość, w związku z czym ma niewielki wpływ na kształtowanie zewnętrznego wizerunku } \\
\text { organizacji. }\end{array}$ \\
\hline Zarządczy & $\begin{array}{l}\text { - ma strategiczny wpływ na sposób generowania wartości dodanej; } \\
\text { - reguluje procesy podstawowe i pomocnicze; } \\
\text { - głównym zadaniem jest określenie misji, strategii i zasad działania całej organizacji, w tym monitorowanie efektywności } \\
\text { procesów. }\end{array}$ \\
\hline
\end{tabular}




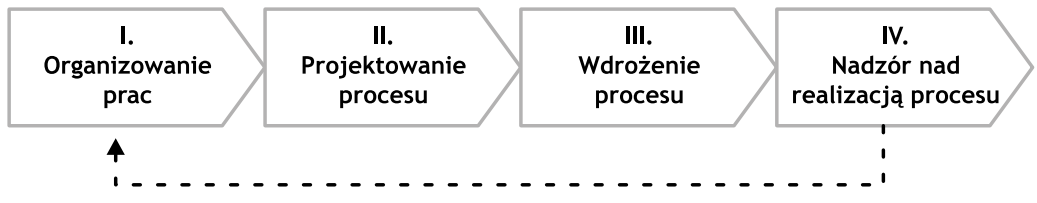

Rys. 1. Fazy implementacji modelu procesowego

Źródto: opracowanie wtasne

Jak wskazują doświadczenia autorów, implementacja modelu procesowego przebiegać może w czterech fazach (rys. 1).

Do pierwszej grupy (organizowanie prac) zaliczyć można takie działania, jak: wybór procesu do opracowania i wdrożenia, wyznaczenie celu ogólnego realizacji procesów, utworzenie zespołu projektowo-wdrożeniowego, zorganizowanie pracy zespołu projektowo-wdrożeniowego czy sporządzenie planu pracy zespołu projektowo-wdrożeniowego. W drugim etapie - projektowanie procesu - istotnym elementem działania jest: zebranie informacji potrzebnych do zaprojektowania procesu, zdefiniowanie procesu (określenie zakresu), określenie szczegółowych warunków i wymagań realizacji procesu (sprecyzowanie celu), określenie struktury procesu (podział, powiązania), sprecyzowanie wymagań i warunków dla części składowych procesu (pakietów roboczych), określenie wymagań, co do procesów wspierających, wyznaczenie wykonawców części składowych procesu oraz opracowania kompletnej dokumentacji procesu (mapa procesu, instrukcje itd.). W przypadku trzeciego kroku - wdrożenie procesu - nieodzowne staje się: powołanie kierownictwa procesu, przydział obowiązków i uprawnień kierownictwu procesu, przeszkolenie kierownictwa i wykonawców procesu w zakresie zaprojektowanych rozwiązań, zorganizowanie wykonawstwa procesu (zaopatrzenie, finanse, wyposażenie, wykonawcy, informacja i inne), testowanie realizacji procesu, a także uruchomienie realizacji procesu. Ostatni etap - nadzór nad realizacją procesu - obejmuje: kontrolę i koordynację realizacji procesu, ocenę wyników i przebiegu realizacji procesu oraz formułowanie wniosków dotyczących usprawnień procesu.

\section{Modele dojrzałości procesowej przedsiębiorstwa}

$\mathbf{L}$ iteratura przedmiotu wskazuje na wiele modeli dojrzałości procesowej. Podzielić je można na odnoszące się do stanu poszczególnych procesów w organizacji oraz takie, które przedstawiają dojrzałość procesową organizacji jako całości (Röglinger i in., 2012). Modelem, na którym wzorowana była znaczna część modeli dojrzałości procesowej, jest model CMM (Capability Maturity Model). Skuteczność modelu zaowocowała jego zaadaptowaniem na potrzeby innych branż poprzez tworzenie kolejnych wersji. W 2001 roku w wyniku ewolucji modelu CMM powstała koncepcja CMMI (CMM Integration), wyróżniająca pięć poziomów dojrzałości procesowej (Jurczuk, 2013, s. 13; Bartkowiak i in., 2019, s. 24). Natomiast w Business Process Maturity Model
(BPMM) poziomy modelu odnoszą się nie tylko do aspektu procesu, ale skupiają się na sposobie zarządzania i postawionym celu (Krukowski, 2016, s. 158). Grupą modeli, prezentującą bardziej holistyczne podejście do dojrzałości procesowej organizacji, są te, które przy ocenie nie koncentrują się tylko na samych procesach, ale także na innych obszarach, uznając je za kluczowe w osiąganiu poszczególnych poziomów dojrzałości procesowej (Raczyńska, 2017, s. 61-73). Zaliczyć do nich należy model D.M. Fishera, badający pięć obszarów (strategię, kontrolę, orientację procesową, pracowników i technologię), mających wpływ na rozwój procesowy organizacji (Fisher, 2004, s. 1-7).

Wielowymiarowym modelem oceny dojrzałości procesowej jest Model Dojrzałości Procesów i Przedsiębiorstwa Michela Hammera (ang. Process and Enterprise Maturity Model - PEMM), który określa cztery poziomy siły czynników umożliwiających proces (P-1, P-2, P-3, P-4) (Hammer, 2007). W modelu tym M. Hammer (2007, s. 112-121) wyróżnił dwie grupy czynników determinujących sprawną realizację procesu. Są to czynniki umożliwiające realizację procesu oraz zdolności organizacyjne. Pierwsza grupa czynników wskazuje, na ile proces może poprawnie funkcjonować w dłuższym czasie, a uwzględnia się tutaj:

- projekt, który obejmuje całościowe podejście do opisu sposobu realizacji procesu poprzez stopień sprecyzowania celu, znajomości oczekiwań klientów oraz zakres przygotowanej dokumentacji;

- wykonawców, a w szczególności mowa jest tu o wiedzy i umiejętnościach pracowników uczestniczących $\mathrm{w}$ realizacji procesu, a także ich stopniu samodzielności i otwartości na wprowadzanie zmian;

- menedżera procesu jako osoby ponoszącej odpowiedzialność za proces i jego rezultaty z uwzględnieniem jego pozycji w organizacji, zakresu władzy i odpowiedzialności;

- infrastrukturę, w skład której wchodzą przede wszystkim stosowane systemy informatyczne wspomagające realizację procesu oraz sposoby zarządzania zasobami ludzkimi;

- mierniki wykorzystywane w przedsiębiorstwie odzwierciedlające sposoby pomiaru wyników procesów oraz zestawy wskaźników wykorzystywanych do oceny efektywności procesu, a także umiejętności ich stosowania w praktyce.

Kluczowe zdolności organizacyjne mają natomiast odzwierciedlenie w:

- przywództwie rozumianym jako wspieranie przebiegu procesu przez kadrę kierowniczą, której poziom świadomości procesowej jest bardzo wysoki; 
- kulturze organizacyjnej akcentującej koncentrację na kliencie, pracy zespołowej, odpowiedzialności osobistej i ukierunkowaniu na wprowadzanie zmian w przebiegu procesów;

- kompetencjach postrzeganych jako niezbędne umiejętności w zakresie projektowania procesów, przejawiające się poziomem wiedzy i umiejętności pracowników w zakresie zarządzania procesami, a także stosowane $\mathrm{w}$ organizacji metody prowadzania zmian w procesach;

- nadzorze, który obejmuje mechanizmy zarządzania złożonymi procesami w ramach przyjętej koncepcji biznesowej, podział odpowiedzialności z tym związany oraz stopień integracji procesów zarówno wewnątrz organizacji, jak i z uwzględnieniem podmiotów zewnętrznych, w tym działań podejmowanych przez klientów (Hammer, 2007, s. 112-121).

W tabeli 2 przedstawiono narzędzie wykorzystywane do diagnozy realizowanych procesów. Dla każdego z wymiarów prezentowany model PEMM wskazuje konkretne kryteria cząstkowe oceny, a dla każdego kryterium w sposób opisowy (jakościowy) wymogi, jakie należy spełnić, aby dla danego kryterium osiągnąć jeden z 4 poziomów dojrzałości. Warunkiem wejścia organizacji na określony poziom dojrzałości procesowej jest uzyskanie tego poziomu przez wszystkie elementy składowe oceny dojrzałości procesowej w modelu PEMM. Oznacza to, że jeśli choć jeden $\mathrm{z}$ elementów nie znajduje się na poziomie P1, dojrzałość procesowa całego przedsiębiorstwa jest oceniana na poziomie P0.

\section{Fazy rozwoju organizacji}

7 miany w organizacjach są nieodzownym warun$\angle$ kiem, z jednej strony, przetrwania w turbulentnym otoczeniu, a z drugiej, najbardziej charakterystycznym przejawem rozwoju. Rozwój organizacji wykazuje pewne prawidłowości, dlatego też wszelkie zachodzące wówczas zjawiska są poddane procesowi badania,

Tabela 2. Ocena dojrzałości procesów i organizacji za pomocą modelu PEMM

\begin{tabular}{|c|c|c|c|c|c|c|c|c|c|c|c|}
\hline \multicolumn{12}{|c|}{ OCENA DOJRZAŁOŚCI } \\
\hline \multicolumn{6}{|c|}{ Procesów } & \multicolumn{6}{|c|}{ Organizacji } \\
\hline \multirow{2}{*}{\multicolumn{2}{|c|}{ ELEMENTY OCENY }} & \multicolumn{4}{|c|}{ Poziom dojrzałości } & \multirow{2}{*}{\multicolumn{2}{|c|}{ ELEMENTY OCENY }} & \multicolumn{4}{|c|}{ Poziom dojrzałości } \\
\hline & & P1 & P2 & P3 & P4 & & & E1 & E2 & E3 & E4 \\
\hline \multirow{3}{*}{ 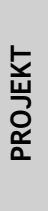 } & Cel & & & & & \multirow{4}{*}{ 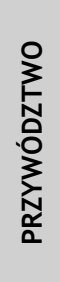 } & Świadomość & & & & \\
\hline & Kontekst & & & & & & Dopasowanie & & & & \\
\hline & Dokumentacja & & & & & & Zachowanie & & & & \\
\hline \multirow{3}{*}{ 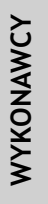 } & Wiedza & & & & & & Styl & & & & \\
\hline & Umiejętności & & & & & \multirow{4}{*}{ 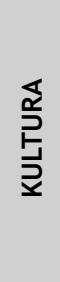 } & Praca zespołowa & & & & \\
\hline & Zachowania & & & & & & Koncentracja na kliencie & & & & \\
\hline \multirow{3}{*}{ 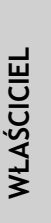 } & Tożsamość & & & & & & Odpowiedzialność & & & & \\
\hline & Działania & & & & & & Stosunek do zmian & & & & \\
\hline & Zakres wiedzy & & & & & \multirow{2}{*}{ 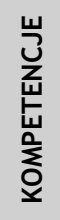 } & Ludzie & & & & \\
\hline \multirow{2}{*}{ 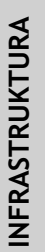 } & Systemy informatyczne & & & & & & Metodologia & & & & \\
\hline & $\begin{array}{c}\text { Systemy zarządzania } \\
\text { zasobami ludzkimi }\end{array}$ & & & & & \multirow{3}{*}{$\begin{array}{l}\text { ơ } \\
\text { zo } \\
\text { ż }\end{array}$} & Model procesu & & & & \\
\hline \multirow{2}{*}{ 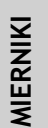 } & Definicja & & & & & & Odpowiedzialność & & & & \\
\hline & Zastosowanie & & & & & & Integracja & & & & \\
\hline
\end{tabular}

Źródto: Hammer, 2007, s. 112 
a znajomość opisanych i rozpoznanych reguł $\mathrm{w}$ tym zakresie może stać się podstawą doskonalenia jego planowania i kontrolowania (Machaczka, 1998, s. 7).

Jedną z teorii reprezentującą taką perspektywę jest teoria cyklu życia organizacji Larry’ego Greinera, która przedstawia rozwój przedsiębiorstwa jako występujące naprzemian procesy ewolucji i rewolucji, rozpatrywane ze względu na jego wiek, wielkość oraz stopę wzrostu gałęzi przemysłu, w której działa dane przedsiębiorstwo. Okres ten nazywany jest okresem wstrząsów i zamieszania. Dlatego też każda faza ewolucji kreuje charakterystyczny dla niej kryzys. W każdym z tych kryzysów konieczne staje się doskonalenie struktury i stylu kierowania, systemu motywacji oraz kontroli (Greiner, 1972, s. 37-46).

Według L. Greinera (1972, s. 37-46), w pierwszej fazie istnienia organizacji jej wzrost dokonuje się głównie za pomocą przedsiębiorczości i talentów organizatorskich jej właściciela lub menedżera. W pewnym momencie nie jest on już jednak w stanie osobiście koordynować i kontrolować pracy coraz większej liczby pracowników, a jednocześnie ciągle nie jest skłonny do delegowania swoich dotychczasowych uprawnień. Jest to kryzys przywództwa.

Charakterystyczne dla drugiego etapu rozwoju organizacji jest scentralizowanie struktur i sformalizowanie sztywnych zasad funkcjonowania, które prowadzi, przy dalszym wzroście organizacji, do nowych problemów wynikających z braku autonomii menedżerów niższych szczebli zarządzania. Aby nie utracić do końca kontroli nad organizacją, zarządzający zmuszeni są do decentralizacji i nadania niezbędnych uprawnień menedżerom niższych szczebli. Powszechnie stosowaną formą zmiany struktury jest w tej fazie dywizjonalizacja i daleko posunięta samodzielność wyodrębnionych oddziałów organizacji. Kryzys pojawia się wówczas, gdy usamodzielnione części zaczynają żyć własnym życiem albo dbać przede wszystkim o swoje własne interesy, wymykając się założeniom opracowywanym przez kadrę menedżerską. Jest to kryzys kontroli. W takiej sytuacji zmiany mogą zostać wdrożone dwukierunkowo: poprzez powrót w organizacji do centralizacji albo rozwój w organizacji skomplikowanych mechanizmów współpracy, konsultacji, uzgodnień, zbiorowego poszukiwania rozwiązań i możliwych do zaakceptowania kompromisów. Mechanizm współpracy i negocjacji ma jednak tę wadę, że przedłuża często procesy decyzyjne. Tak wypracowane decyzje bywają też często dalekie od doskonałości, ponieważ stają się wypadkową różnych cząstkowych interesów i zawieranych kompromisów. Na bazie tak ukształtowanej sytuacji może tworzyć się nowy kryzys - kryzys współpracy (Koźmiński, 2000, s. 85).

Podsumowując, podkreślić należy, że podejście procesowe we współczesnym dynamicznym otoczeniu przedsiębiorstwa ma na celu przede wszystkim uruchomienie myślenia, pozwalającego lepiej zrozumieć i tym samym usprawnić sekwencję działań w organizacji. Menedżerowie przedsiębiorstwa, dążąc do poprawy obszarów swojego funkcjonowania, zarówno w kontekście jakości, efektywności, komunikacji, jak i reagowania na potrzeby otoczenia, powinni dostrzegać konieczność wdrażania zarządzania procesowego.

\section{Kierunki implementacji zarządzania procesowego w przedsiębiorstwie - studium przypadku}

\section{Opis podmiotu badawczego}

A naliza studium przypadku dotyczy przedsiębiorstwa produkcyjnego działającego na terenie Polski. Procedura diagnostyczna, jak też implementacja zarządzania procesowego przeprowadzona została w latach 2015-2017. Projekt wdrożenia zakładał kilka etapów, w tym zaangażowanie podmiotu zewnętrznego oraz kadry menedżerskiej badanego przedsiębiorstwa. Zebrane i przedstawione $\mathrm{w}$ artykule materiały stanowią syntetyczny opis poszczególnych etapów, wynikających z dostępnych raportów, analiz, a także wywiadów przeprowadzanych na różnych szczeblach organizacyjnych przedsiębiorstwa.

Badane przedsiębiorstwo działa na rynku ponad 130 lat, produkując wyroby gotowe oraz komponenty dla innych producentów, i jest zaliczane do przemysłu maszynowego. Swoją działalność zbudowało na 300 partnerach handlowych zlokalizowanych na terenie całego kraju, sieci inżynierów oraz handlowców docierających bezpośrednio do klientów. Zmiany zachodzące w dynamicznym otoczeniu, brak jasno zdefiniowanych procesów, regulacje przyjmowane na poziomie Unii Europejskiej oraz rosnąca konkurencja wymusiły decyzje na poziomie strategicznym i niezbędne zmiany wewnętrzne. Konieczne stało się także wprowadzenie usprawnień technologicznych, a wraz z nimi podjęto decyzję o zmianach w zarządzaniu i funkcjonowaniu przedsiębiorstwa, ze względu na następujące problemy:

- powolność w działaniu - wykonywanie zadań zbędnych oraz opóźnienia w przekazywaniu pracy;

- niedokładność - wiele błędów wynikających z niezrozumienia poleceń przełożonych i nieprawidłowej interpretacji otrzymanych informacji;

- brak elastyczności - proces jest częścią większej całości;

- niezadowalające usługi - brak dostatecznych informacji oraz niezbędnej perspektywy, pozwalającej wyjaśnić klientom stan procesu, którego rezultatu oczekują;

- wysokie koszty - zbyt duże zatrudnienie;

- hierarchiczną strukturę organizacyjną tworzącą fragmentaryczną perspektywę;

- frustrację wynikającą $\mathrm{z}$ nieefektywnego wykorzystania systemów zintegrowanych - niedostosowanie obiegu informacji, kultury i zwyczajów komunikowania się w ramach przedsiębiorstwa;

- długi czas reakcji na zmiany w otoczeniu zewnętrznym i wewnętrznym jako efekt słabych więzi poziomych;

- niską jakość podejmowanych decyzji - brak rzetelnych danych oraz opomiarowania; 
- dezorientację w działaniu - brak jasno określonych zakresów odpowiedzialności;

- kulturę „silosów”, tj. zamkniętych, niekomunikujących się ze sobą działów przedsiębiorstwa;

- brak poczucia odpowiedzialności za jakość obsługi klienta;

- specjalizację funkcjonalną generującą wśród pracowników rutynę, niechęć do zmian i uczenia się.

\section{Analiza i ocena implementacji zarządzania procesowego}

Przed przystąpieniem do implementacji zarządzania procesowego zarząd przedsiębiorstwa jako niezbędną uznał diagnozę fazy wzrostu, w jakiej w chwili obecnej znajduje się przedsiębiorstwo. Diagnozy fazy wzrostu badanego przedsiębiorstwa dokonano na podstawie modelu Greinera, korzystając z kwestionariusza diagnostycznego rozwoju organizacyjnego Leparda. Kwestionariusz diagnostyczny opracowany został przez zespół, w skład którego wchodził zarząd oraz menedżerowie wyższego szczebla zarządzania. W kwestionariuszu zaznaczano stwierdzenia, które obrazowały sytuację w przedsiębiorstwie. Następnie odpowiedzi naniesiono na arkusz punktacji kwestionariusza diagnostycznego rozwoju organizacyjnego, w którym zaznaczono (czcionka pogrubiona) wskazane odpowiedzi (tab. 3).

Analizując dane zawarte w tabeli 3, stwierdzić można, że badane przedsiębiorstwo znajduje się $\mathrm{w}$ fazie wzrostu przez wytyczne (największa liczba trafnych stwierdzeń):

3 - Kierownictwo koncentruje się przede wszystkim na efektywności działań bieżących;

13 - Struktura organizacyjna przedsiębiorstwa ma charakter scentralizowany i funkcjonalny, tzn. koncentruje się na specjalizacji;

23 - Styl kierowania naczelnego kierownictwa, polega na wydawaniu poleceń;
33 - Główne systemy kontroli, wydają się koncentrować na normach i kosztach.

Oprócz cech dominujących wskazujących na fazę wzrostu przez wytyczne wskazano także na cechy świadczące o wzroście przez kreatywność:

11 - Styl naczelnego kierownictwa można określić jako wysoce indywidualistyczny;

41 - Naczelne kierownictwo koncentruje się głównie na produkcji i sprzedaży;

51 - Naczelne kierownictwo ma bliski kontakt z klientami i dobre rozeznanie co do ich oczekiwań.

W odpowiedzi na zdiagnozowaną fazę wzrostu przez wytyczne podjęto decyzję o wyodrębnieniu w strukturze względnie samodzielnych dywizji, które zostały wyposażone w znaczną autonomię w zakresie uprawnień decyzyjnych i odpowiedzialności. Autonomia dywizji nie była jednak pełna, tj. decyzyjność ograniczała się do określonego zakresu działań. Dywizje podlegały zarządowi, który określał cele strategiczne dla całego przedsiębiorstwa i sprawował nadzór nad ich realizacją, a także koordynował działalność obu dywizji. Na podstawie otrzymanych wyników zarząd przedsiębiorstwa podjął decyzję o implementacji zarządzania procesowego w organizacji.

\section{Etapy implementacji zarządzania procesowego w przedsiębiorstwie}

Projekt wdrożenia tego typu zarządzania zakładał kilka etapów, w tym zaangażowanie podmiotu zewnętrznego oraz kadry menedżerskiej badanego przedsiębiorstwa. Podmiot zewnętrzny przeprowadził analizę sytuacji wewnątrz przedsiębiorstwa oraz otoczenia, w jakim ono funkcjonuje. Diagnozie zostały poddane wszystkie działy struktury dywizjonalnej. Z grona menedżerów wybrano tzw. koordynatorów, którzy współpracowali w określonych obszarach z podmiotem zewnętrznym. Pracę koordynatorów nadzorował lider.

Tabela 3. Wyniki punktacji kwestionariusza diagnostycznego rozwoju organizacji

\begin{tabular}{|c|c|c|c|c|c|c|c|c|c|}
\hline \multicolumn{2}{|c|}{ Etap 1} & \multicolumn{2}{|c|}{ Etap 2} & \multicolumn{2}{|c|}{ Etap 3} & \multicolumn{2}{|c|}{ Etap 4} & \multicolumn{2}{|c|}{ Etap 5} \\
\hline 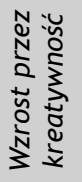 & 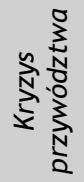 & 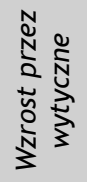 & 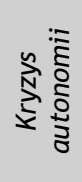 & 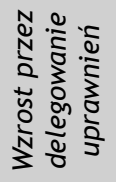 & 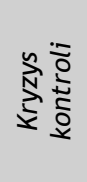 & 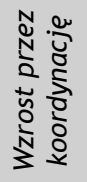 & 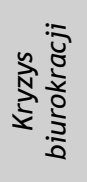 & 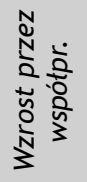 & 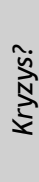 \\
\hline 1 & 2 & 3 & 4 & 5 & 6 & 7 & 8 & 9 & 10 \\
\hline 11 & 12 & 13 & 14 & 15 & 16 & 17 & 18 & 19 & 20 \\
\hline 21 & 22 & 23 & 24 & 25 & 26 & 27 & 28 & 29 & 30 \\
\hline 31 & 32 & 33 & 34 & 35 & 36 & 37 & 38 & 39 & 40 \\
\hline 41 & 42 & 43 & 44 & 45 & 46 & 47 & 48 & 49 & 50 \\
\hline 51 & 52 & 53 & 54 & 55 & 56 & 57 & 58 & 59 & 60 \\
\hline 3 & 1 & 4 & 0 & 1 & $\mathbf{0}$ & 1 & 0 & 2 & $\mathbf{0}$ \\
\hline
\end{tabular}

Źródło: opracowanie własne 
W drugim etapie projektu, został przeprowadzony cykl szkoleń mający na celu przygotowanie pracowników do zarządzania procesowego, aby $\mathrm{w}$ trzecim etapie powołać trzy zespoły: Zespół Procesowy (grupa koordynująca zmianę - przyszli właściciele procesów i głównych podprocesów - aktualne kierownictwo; konsultanci - firma zewnętrzna; eksperci), Zespół Projektowy (przyszli właściciele podprocesów - aktualny średni szczebel zarządzania oraz eksperci) i Zespół Zadaniowy (przyszli uczestnicy procesów i podprocesów - aktualni pracownicy operacyjni), których zadaniem było rozstrzyganie pojawiających się nowych problemów, akceptacja rozwiązań, przygotowanych na niższych szczeblach organizacyjnych, stabilizacja przedsiębiorstwa $\mathrm{w}$ procesie zmian, wprowadzanie nowego modelu wartości kultury organizacyjnej, zbieranie i ocena pomysłów prezentowanych przez Zespoły Zadaniowe, projektowanie rozwiązań, przedstawianie projektów do analizy, a także analizowanie problemów (własnych i zadanych przez grupę projektową) oraz wspieranie rozwiązywania problemów.

Zespół Procesowy we współpracy z grupą referencyjną, opracował procesy, zgodnie z którymi zakładano funkcjonowanie przedsiębiorstwa. Powstały dwie grupy procesów obejmujące: proces zarządzania finansami oraz proces zarządzania zasobami ludzkimi i wiedzą (pierwsza grupa), a także proces zarządzania jakością, proces logistyki, proces kreowania popytu i sprzedaży, proces produkcji i technologii, proces zarządzania informacją i obiegiem dokumentów oraz proces usług technicznych (druga grupa). Liderami Zespołów Projektowych zostali przyszli właściciele procesów.

Właściciele podprocesów automatycznie stawali się liderami Zespołów Zadaniowych, w skład których wchodzili pracownicy różnych komórek, które w przyszłości miały brać udział $w$ danych procesach.

Ważnym elementem projektu stała się zmiana struktury organizacyjnej. Funkcjonująca od lat struktura dywizjonalna zastąpiona została strukturą macierzową. W nowo zaprojektowanej strukturze można było wyróżnić dwa procesy główne, tj. proces produkcyjno-sprzedażowy oraz proces pomocniczy. W procesach głównych znalazły się podprocesy, dla których wskazani zostali ich właściciele. Wywołało to $\mathrm{w}$ przedsiębiorstwie niepokój, frustracje i strach przed utratą pozycji i wpływów. Dotychczasowi kierownicy, bojąc się utraty „władzy”, hamowali często wdrożenie poszczególnych rozwiązań, nie pomagając w przeprowadzaniu zmian, co gorsza przekazywali sygnały w dół o braku konieczności przedmiotowych zmian czy ewentualnych zagrożeniach.

\section{Tabela 4. Założenia poziomu P-1}

\begin{tabular}{|c|c|c|}
\hline \multicolumn{3}{|r|}{ Założenia poziomu P-1 } \\
\hline \multirow{3}{*}{$\frac{\ddot{z}}{\frac{\pi}{0}}$} & Cel & $\begin{array}{l}\text { Proces nie został zaprojektowany całościowo. Menedżerowie poszczególnych działów wykorzystują dotychczasowe } \\
\text { projekty głównie w kontekście poprawy wyników swoich działów. }\end{array}$ \\
\hline & Kontekst & Określono nakłady na proces, jego wyniki oraz dostawców i klientów. \\
\hline & Dokumentacja & $\begin{array}{l}\text { Dokumentacja procesu ma przede wszystkim charakter funkcjonalny, ale określa wzajemne powiązania pomiędzy } \\
\text { jednostkami zaangażowanymi w wykonanie procesu. }\end{array}$ \\
\hline \multirow{3}{*}{ 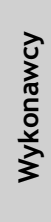 } & Wiedza & Wykonawcy są w stanie nazwać proces, który realizują, i określić najważniejsze metody pomiaru jego efektywności. \\
\hline & Umiejętności & Wykonawcy umieją rozwiązywać problemy i znają techniki usprawniania procesu. \\
\hline & Zachowania & $\begin{array}{l}\text { Wykonawcy czują pewną przynależność do zespołu realizującego proces, jednak przede wszystkim - do swojego } \\
\text { działu. }\end{array}$ \\
\hline \multirow{3}{*}{$\begin{array}{l}\bar{d} \\
\frac{d u}{u} \\
y \\
\bar{z} \\
\end{array}$} & Tożsamość & Właściciel procesu to osoba lub grupa, do której nieformalnych obowiązków należy poprawa wyników procesu. \\
\hline & Działania & $\begin{array}{l}\text { Właściciel procesu wyodrębnia i dokumentuje proces, informuje o nim wszystkich wykonawców i odpowiada za } \\
\text { projekty zmian na mniejszą skalę. }\end{array}$ \\
\hline & Zakresy władzy & $\begin{array}{l}\text { Właściciel procesu lobbuje na rzecz procesu, może jednak co najwyżej zachęcać menedżerów poszczególnych działów } \\
\text { do wprowadzania zmian. }\end{array}$ \\
\hline \multirow{2}{*}{ 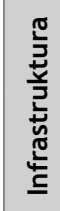 } & $\begin{array}{l}\text { Systemy } \\
\text { informatyczne }\end{array}$ & Wsparcie dla procesu stanowią fragmentaryczne systemy IT istniejące dotychczas w firmie. \\
\hline & $\begin{array}{c}\text { System } \\
\text { zarządzania } \\
\text { zasobami ludzkimi }\end{array}$ & $\begin{array}{l}\text { Menedżerowie działów nagradzają wyniki osiągane w skali działu oraz rozwiązywanie problemów działu w kontekście } \\
\text { procesu. }\end{array}$ \\
\hline \multirow{2}{*}{ 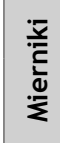 } & Definicja & Proces posiada pewne podstawowe mierniki kosztów i jakości. \\
\hline & Zastosowanie & $\begin{array}{l}\text { Menedżerowie używają mierników procesu do śledzenia jego efektów, wykrywania podstawowych przyczyn } \\
\text { uzyskiwania złych wyników i do wprowadzania ulepszeń w obrębie działów. }\end{array}$ \\
\hline
\end{tabular}

Źródło: opracowanie własne na podstawie materiałów wewnętrznych przedsiębiorstwa 


\section{Ocena powdrożeniowa}

z wykorzystaniem

Modelu Dojrzałości Procesów i Przedsiębiorstwa

B adania dotyczące dojrzałości procesów i przedsiębiorstwa przeprowadzono $\mathrm{w}$ trzech grupach pracowników przedsiębiorstwa, tj. wyższej kadrze kierowniczej, grupie menedżerów średniego szczebla oraz pracowników liniowych. Otrzymane wyniki pozwalają na stwierdzenie, że wśród kadry kierowniczej i menedżerów średniego szczebla postrzeganie organizacji jest inne niż wśród pracowników liniowych. Według pracowników liniowych, przedsiębiorstwo znajduje się na poziomie P-0, czyli przedsiębiorstwo ma procesy, których przebieg jest chaotyczny. Wnioski z tej analizy są następujące:

- proces nie został zaprojektowany całościowo, menedżerowie sporadycznie wykorzystują reengineering do poprawy wyników swoich działów;

- nie określono nakładów na proces, jego wyniki oraz dostawców i klientów;

- brak jest dokumentacji procesu, nie są zapisane powiązania pomiędzy jednostkami funkcjonalnymi zaangażowanymi w wykonanie procesu;
- wykonawcy nie są w stanie jednoznacznie nazwać proces, który realizują i określić najważniejsze metody pomiaru jego efektywności;

- wykonawcy nie potrafią rozwiązywać problemów i nie znają techniki usprawniania procesu, jak również nie czują przynależności do zespołu realizującego proces, przede wszystkim - do swojego działu;

- proces posiada pewne podstawowe mierniki kosztów i jakości, lecz nie do końca są one rozumiane przez pracowników;

- nie wszyscy menedżerowie używają mierników procesu do śledzenia jego efektów i wykrywania podstawowych przyczyn uzyskiwania złych wyników i do wprowadzania ulepszeń w obrębie działów.

Natomiast analiza modelu dojrzałości procesowej według kadry kierowniczej i menedżerów średniego szczebla pozwala na stwierdzenie, iż:

- wykonawcy są w stanie opisać ogólny przebieg procesu oraz sposób, w jaki ich praca wpływa na klientów, na innych pracowników oraz na wskaźniki efektywności procesu, a także podać wymagany i obecny poziom tych wskaźników;

- wykonawcy umieją rozwiązywać problemy i znają techniki usprawniania procesu;

Tabela 5. Zatożenia poziomu E-1

\begin{tabular}{|c|c|c|}
\hline \multicolumn{3}{|r|}{ Założenia poziomu E-1 } \\
\hline \multirow{4}{*}{ 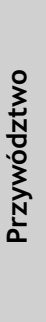 } & Świadomość & $\begin{array}{l}\text { Kierownictwo wyższego szczebla dostrzega konieczność poprawy wyników operacyjnych, ale ma ograniczone } \\
\text { zrozumienie znaczenia procesów biznesowych. }\end{array}$ \\
\hline & Dopasowanie & Kierownictwo programu wdrażania lub zmiany procesów objął menedżer średniego szczebla. \\
\hline & Zachowania & Menedżer wyższego szczebla udziela swojego poparcia i inwestuje w usprawnienia operacyjne. \\
\hline & Styl & $\begin{array}{l}\text { Kierownictwo wyższego szczebla przechodzi z nakazowego, hierarchicznego stylu zarządzania na styl bardziej otwarty } \\
\text { i oparty na współpracy. }\end{array}$ \\
\hline \multirow{4}{*}{$\begin{array}{l}\frac{0}{3} \\
\frac{1}{3} \\
\underline{2}\end{array}$} & Praca zespołowa & Praca zespołowa jest zorientowana na proces, zdarza się od czasu do czasu i nie jest typowym zjawiskiem w firmie. \\
\hline & $\begin{array}{l}\text { Koncentracja } \\
\text { na kliencie }\end{array}$ & $\begin{array}{l}\text { Istnieje powszechne przekonanie, że koncentracja na kliencie ma duże znaczenie, ale zrozumienie, co to właściwie } \\
\text { oznacza, jest ograniczone. }\end{array}$ \\
\hline & Odpowiedzialność & Odpowiedzialność za wyniki spoczywa na menedżerach. \\
\hline & Stosunek do zmian & W przedsiębiorstwie rośnie akceptacja dla konieczności przeprowadzenia zmian. \\
\hline \multirow{2}{*}{ 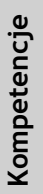 } & Ludzie & W firmie istnieje niewielka grupa ludzi, która potrafi docenić znaczenie procesów. \\
\hline & Metodyka & $\begin{array}{l}\text { Przedsiębiorstwo wykorzystuje jedną lub więcej metodyk przy rozwiązywaniu problemów wykonawczych } \\
\text { i dokonywaniu stopniowych ulepszeń w procesach. }\end{array}$ \\
\hline \multirow{3}{*}{ 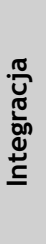 } & Model procesu & Przedsiębiorstwo wyodrębniło niektóre procesy biznesowe. \\
\hline & Odpowiedzialność & $\begin{array}{l}\text { Menedżerowie działów są odpowiedzialni za wyniki, zaś menedżerowie projektu - za inicjatywy związane } \\
\text { z ulepszeniami w procesach. }\end{array}$ \\
\hline & Integracja & $\begin{array}{l}\text { Jedna lub więcej grup oręduje na rzecz odrębnych technik wprowadzania ulepszeń operacyjnych i udziela im } \\
\text { wsparcia. }\end{array}$ \\
\hline
\end{tabular}

Źródło: opracowanie wtasne na podstawie materiałów wewnętrznych przedsiębiorstwa 
- przywódcy przedsiębiorstwa ustanowili oficjalną funkcję właściciela procesu i powołali na to stanowisko menedżera wyższego szczebla;

- właściciel procesu wyodrębnia i dokumentuje proces, informuje o nim wszystkich wykonawców i odpowiada za projekty zmian na mniejszą skalę, jak również lobbuje na rzecz procesu, zachęcając menedżerów poszczególnych działów do wprowadzania zmian.

Przy ocenie dojrzałości przedsiębiorstwa różnice pomiędzy kadrą kierowniczą i menedżerami średniego szczebla a wykonawcami były bardzo niewielkie. Przy ustalaniu modelu dojrzałości organizacji według wykonawców procesów otrzymano wyniki, które pozwalają stwierdzić, iż:

- kierownictwo wyższego szczebla dostrzega konieczność poprawy wyników operacyjnych, ale ma ograniczone zrozumienie znaczenia procesów biznesowych;

- przywództwo programu związanego $\mathrm{z}$ procesem oraz odpowiedzialność przyjął na siebie menedżer wyższego szczebla;

- menedżer wyższego szczebla udziela swojego poparcia i inwestuje w usprawnienia operacyjne;

- praca zespołowa jest zorientowana na proces, ale nie jest to zjawisko stałe;

- istnieje powszechne przekonanie, że koncentracja na kliencie ma duże znaczenie, ale zrozumienie, co to właściwie oznacza, jest ograniczone;

- odpowiedzialność za wyniki spoczywa na menedżerach;

- w przedsiębiorstwie rośnie akceptacja dla konieczności przeprowadzenia drobnych zmian;

- istnieje niewielka grupa pracowników, która potrafi docenić znaczenie procesów;

- przedsiębiorstwo wyodrębniło niektóre procesy biznesowe;

- menedżerowie działów są odpowiedzialni za wyniki, zaś menedżerowie projektu - za inicjatywy związane $\mathrm{z}$ ulepszeniami w procesach.

W przypadku modelu dojrzałości organizacji według kadry kierowniczej i menedżerów średniego szczebla wyniki badania przedstawiają się następująco:

- menedżer wyższego szczebla publicznie określił ambitne cele dotyczące poprawy wyników z punktu widzenia nabywcy. By zrealizować te cele, jest gotowy zaangażować zasoby, przeprowadzić głębokie zmiany i usunąć przeszkody;

- kierownictwo wyższego szczebla, kierujące programem procesów, podchodzi z pasją do konieczności wprowadzenia zmian i do samych procesów jako podstawowego narzędzia tych zmian;

- kierownictwo wyższego szczebla przechodzi z nakazowego, hierarchicznego stylu zarządzania na styl bardziej otwarty i oparty na współpracy.

Przy ocenie dojrzałości procesowej największe różnice $\mathrm{w}$ postrzeganiu przedsiębiorstwa między wykonawcami procesu a kadrą zarządzającą dotyczą wiedzy na temat projektu, co świadczy o niewystarczającym wyedukowaniu i informowaniu pracowników o projekcie. Wykonawcy nie znają celu projektu, nie mają również dokumentacji. Menedżerom wydaje się, że pracownicy wiedzą, jak usprawniać projekt, gdy zaś wykonawcy procesów nie we wszystkim się orientują. Przy ocenie dojrzałości przedsiębiorstwa największe różnice $\mathrm{w}$ postrzeganiu organizacji są $\mathrm{w}$ zakresie przywództwa (świadomość, dopasowanie, styl). Brak ustalonych odpowiedzialności za przebieg procesu skutkuje poczuciem, że to tylko menedżer odpowiada za ostateczny wynik.

Dokonując całościowej analizy wyników dotyczących dojrzałości przedsiębiorstwa, można przyjąć, że organizacja jest na poziomie E-1 (tab. 5). Gdy przedsiębiorstwo posiada zdolności na poziomie E-1 w zakresie przywództwa, kultury, kompetencji i nadzoru, jest gotowe na wprowadzenie procesów na poziom P-1 (tab. 4) (szczegółową metodykę oceny poziomów przedstawiono we wcześniejszej części artykułu).

Jak wynika z przeprowadzonej oceny, kierownictwo posiada świadomość procesów, wyodrębniło niektóre procesy biznesowe, lecz nie zawsze widzi zależność pomiędzy poprawą wyników operacyjnych poprzez ulepszanie procesów. Większość zmian projektowana i wdrażana jest poprzez menedżerów średniego szczebla. Menedżerowie ci nie do końca rozumieją swoją rolę $\mathrm{w}$ organizacji procesowej, nie wszyscy odchodzą od hierarchicznego stylu zarządzania na rzecz stylu bardziej otwartego i opartego na współpracy. Ważnym elementem jest czynnik ludzki, który docenia znaczenie procesów i akceptuje konieczność przeprowadzenia zmian.

\section{Podsumowanie}

kuteczne i efektywne wdrożenie zarządzania proceso$\checkmark$ wego jest wyzwaniem dla wielu współczesnych organizacji. W badanym przedsiębiorstwie proces wdrożenia nie zakończył się pełnym sukcesem. Jak wynika z przedstawionych badań, kluczowymi czynnikami sukcesu dotyczącymi wdrożenia zarządzania procesowego są:

- właściwa edukacja oraz kampania komunikacyjna, która towarzyszyć powinna na każdym etapie procesu;

- kadra menedżerska, której podstawowym zadaniem w procesie, oprócz działań bezpośrednich, jest przekonywanie pracowników liniowych i ograniczanie potencjalnych ryzyk;

- kadra menedżerska wyższego szczebla przekonana o idei wdrożenia, kreująca właściwą kulturę organizacyjną, przyjazną zmianom;

- pracownicy kreujący określone zachowania w przedsiębiorstwie stanowią najważniejszy element wdrożenia.

Przedstawione $\mathrm{w}$ artykule rozważania badawcze obejmują analizę jednego przedsiębiorstwa, regulowanego nie tylko przez zewnętrzne akty prawne, ale także specyfikę branży, co wskazuje na pewne ograniczenia. Kierunki kolejnych prac badawczych, dotyczących zarówno faz rozwoju organizacji, jak i powiązanych z nimi możliwości implementacji zarządzania procesowego powinny dotyczyć przedsiębiorstw $\mathrm{z}$ różnych branż, a nawet całych sektorów gospodarki. 
dr hab. Piotr Bartkowiak, prof. uczelni Uniwersytet Ekonomiczny w Poznaniu Instytut Zarządzania

ORCID: 0000-0001-9678-3465

e-mail: piotr.bartkowiak@ue.poznan.pl

\section{mgr Izabela Grabowska \\ Collegium da Vinci \\ Wydział Nauk Społecznych \\ ORCID: 0000-0002-4202-2393 \\ e-mail: izabela.grabowska1@cdv.pl}

\section{Bibliografia}

[1] Bartkowiak P., Rutkowski I.P. (2016), Informacja w kształtowaniu procesu innowacji produktu, „Przegląd Organizacji”, $\mathrm{Nr}$ 3, s. 34-42.

[2] Bartkowiak P., Rutkowski I.P., Bartkowiak A. (2019), Measuring and Improving the Innovation Process of a New Product, „Przedsiębiorczość i Zarządzanie”, T. XX, z. 1, cz. II, s. $21-30$.

[3] Bitkowska A. (2013), Zarządzanie procesowe we współczesnych organizacjach, Difin, Warszawa.

[4] Bitkowska A. (2019), Model architektury procesów, „Przegląd Organizacji”, Nr 2, s. 14-21.

[5] Bitkowska A. (2016), Implementacja zarzadzania procesowego we współczesnych przedsiębiorstwach, „Przegląd Organizacji”, Nr 9, s. 4-11.

[6] Bitkowska A., Kolterman K., Wójcik G.P., Wójcik K. (2011), Zarządzanie procesami $w$ przedsiębiorstwie: aspekty teoretyczno-praktyczne, Difin, Warszawa.

[7] Brilman J. (2002), Nowoczesne koncepcje i metody zarządzania, PWE, Warszawa.

[8] Cieśliński W.B. (2011), Doskonalenie procesowej orientacji przedsiębiorstw. Model platformy treningu procesowego, Wyd. Uniwersytetu Ekonomicznego we Wrocławiu, Wrocław.

[9] Czekaj J. (red.), (2009), Zarządzanie procesami biznesowymi. Aspekt metodyczny, Wyd. Uniwersytetu Ekonomicznego w Krakowie, Kraków.

[10] Fisher D. (2004), The Business Process Maturity Model A Practical Approach for Identifying Opportunities for Optimization, https://www.bptrends.com/bpt/wp-content/ publicationfiles/10-04\%20ART\%20BP\%20Maturity\%20 Model\%20-\%20Fisher.pdf, access date: 11.10.2019.

[11] Grajewski P. (2012), Procesowe zarzadzanie organizacja, PWE, Warszawa.

[12] Grajewski P. (2016), Organizacja procesowa, PWE, Warszawa.

[13] Greiner, L.E. (1972), Evolution and Revolution as Organizations Grow, „Harvard Business Review”, Vol. 50, No. 4, pp. 37-46.

[14] Hammer M., Champy J. (1996), Reengineering w przedsiębiorstwie, Neumann Management Institute, Warszawa.

[15] Hammer M. (2007), The Process Audit „Harvard Business Review", April, pp. 1-13.

[16] Jashapara A. (2011), Knowledle Management: An Integrated Approach, Pearson Financial Times, Prentice Hall, Harlow, Essex, New York.
[17] Jurczuk A. (2013), Procesowa mapa drogowa doskonalenia organizacji z wykorzystaniem modelu CMMI-DEV, „Economics and Management", Vol. 5, Nr 4, s. 9-20.

[18] Koźmiński A.K. (red.), (2000), Zarzq̨dzanie: teoria i prakty$k a$, Wyd. Naukowe PWN, Warszawa.

[19] Krukowski K. (2016), Kulturowe uwarunkowania dojrzałości procesowej Urzędów Miast, Wyd. Naukowe Uniwersytetu Mikołaja Kopernika, Torun.

[20] Machaczka J. (1998), Zarządzanie rozwojem organizacji, Wyd. Naukowe PWN, Warszawa-Kraków.

[21] Nowosielski S. (2011), Podejście procesowe w organizacjach, Wyd. Uniwersytetu Ekonomicznego we Wrocławiu, Wrocław.

[22] Raczyńska M., Modele d dojrzałości procesowej organizacji, "Acta Universitatis Nicolai Copernici, Zarządzanie”, XLIV, Nr 2, s. 61-73.

[23] Röglinger M., Pöppelbuß J., Becker J. (2012), Maturity Models in Business Process Management, „Business Process Management Journal”, Vol. 18, No. 2, pp. 2-19.

[24] Szelągowski M. (2015), Dynamiczne zarządzanie procesowe - teoria i praktyka, [w:] A. Bitkowska, E. Weiss (red.), Zarzqdzanie procesowe $w$ organizacjach. Teoria i praktyka, Wyd. Vizja Press\&IT, Warszawa, s. 26-35.

[25] Weiss E. (2012), Instrumenty podejścia procesowego $w z a-$ rządzaniu przedsiębiorstwem, Zeszyty Naukowe Uniwersytetu Szczecińskiego, Nr 737 - Finanse, Rynki Finansowe, Ubezpieczenia, $\mathrm{Nr}$ 56, s. 261-283.

[26] Winiowski L. (2016), Założenia metodyczne dla definiowania faz wdrażania zarzadzania procesowego na przykładzie wybranych przedsiębiorstw przemysłowych, „Przegląd Organizacji”, Nr 11, s. 21-27.

\section{Implementation of Business Process Management in Production Enterprise}

\section{Summary}

For a modern company implementation of business process management is on the one hand a huge challenge, on the other hand it is a chance for building a competitive advantage in the variable and globalising market surrounding. Undoubtedly, an organisation's readiness to change as well as the phase of growth and the stage of processes maturity influence a successful implementation. The aim of this article is to identify the growth phase, implementation of business process management and the post-implementation maturity assessment, both of the processes and the studied enterprise. The article presents a case study and literature studies in the field of carrying out the abovementioned elements. They are a source of knowledge for managers carrying out projects of process management implementation. The presented considerations in the article are both of cognitive as well as application value.

\section{Keywords}

business process management, phase of organisation's growth, Process and Enterprise Maturity Model 